\title{
Microbiological quality assessment of Chapila (Gudusia chapra) and Tengra (Mystus vittatus) in Bangladesh
}

\author{
Md. Abdul Quaiyum, ${ }^{1}$ Md. Mofizur Rahman, ${ }^{1+}$ Bhakta Supratim Sarker, ${ }^{1}$ Md. Masud Alam, ${ }^{2}$ Najmus \\ Sakib Khan, ${ }^{1}$ Mohammad Shamsur Rahman ${ }^{3}$ and Rokeya siddiqui ${ }^{3}$ \\ ${ }^{I}$ Department of Fisheries and Marine Science, Noakhali Science and Technology University, Sonapur, Noakhali-3814, Bangladesh; \\ ${ }^{2}$ Department of Microbiology, Noakhali Science and Technology University, Sonapur, Noakhali-3814, Bangladesh; \\ ${ }^{3}$ Department of Fisheries, University of Dhaka, Dhaka-1000, Bangladesh
}

Received 14 June 2012/Accepted 20 August 2012

\begin{abstract}
Present study was conducted to determine and quantify the occurrence of various types of microorganisms in raw and final products of Chapila (Gudusia chapra) and Tengra (Mystus vittatus) and also to enhance food safety with a view of promoting international trade. Raw and frozen Chapila and Tengra samleswere collected and the microbial analysis was conducted. In case of raw product of Chapila, the aerobic plate count (APC) was $2.6 \times 10^{5} \mathrm{cfu} / \mathrm{g}$, whereas in frozen products, the load was estimated to be $4.0 \times 10^{5} \mathrm{cfu} / \mathrm{g}$. Furthermore, while APC of raw Tengra was $2 \times 10^{5} \mathrm{cfu} / \mathrm{g}$, the APCs were $3.3 \times 10^{6} \mathrm{cfu} / \mathrm{g}$ in frozen product. Total coliform in raw and frozen Chapila was found to be $36.00 \pm 2.3$ $\mathrm{MPN} / \mathrm{g}$ and 7.2 $\pm 1.01 \mathrm{MPN} / \mathrm{g}$, respectively and 27.00 $\pm 5.57 \mathrm{MPN} / \mathrm{g}$ and 9.4 $\pm 3.75 \mathrm{MPN} / \mathrm{g}$, respectively were found in raw and frozen Tengra samples. Moreover, Fecal coliform in frozen samples of Chapila and Tengra was found within the acceptable limit ( $<3 \mathrm{MPN} / \mathrm{g})$. Salmonella spp. and Vibrio cholerae were not detected in any of the raw and frozen Chapila and Tengra samples. Overall, the present study reveals that tested frozen fish samples from the fish processing plant were good enough for export and of better quality than raw fish samples from the microbiological point of view.
\end{abstract}

Key words: Chapila; Tengra; sea fish; microbiolocal quality; coliform

Fisheries is the second amongst the top earning export sectors in Bangladesh and provide direct or indirect employment to about $10 \%$ of total population of the country (1). It contributes $3.74 \%$ in national GDP, $2.7 \%$ in export earnings and $22.23 \%$ in agriculture sector. Some of the common forms of exported items are frozen shrimp and prawn, fresh live fish, frozen fish, dried fish, salted and dehydrated fish etc. The contribution of fish and fishery products in national income, employment, health, nutrition and foreign exchange earnings is increasing $(2,3)$. However, due to insufficient attention towards the standard of hygiene and quality of the product, reasonable numbers of seafood products have gone out of business. Nevertheless, collective efforts by the industry, Bangladesh Department of Fisheries and Bangladesh Frozen Food Exporters Association (BFFEA) have continued to strengthen the export-processing sector. Now 62 plants have EU approval out of 65. EU advised the Bangladesh Government to implement Hazard Analysis and Critical Control Points (HACCP) system in fish and shrimp industries for safe export quality frozen food products (4).

${ }^{\ddagger}$ Corresponding author. Mailing address: Md. Mofizur Rahman, Department of Fisheries and Marine Science, Noakhali Science and Technology University, Sonapur, Noakhali-3814; Email: ripondu31184@ yahoo.com
Chapila (Gudusia chapra) and Tengra (Mystus vittatus) both are small indigenous species (SIS) of fish. Local farmers are mainly interested in large Indian and Chinese major carp's culture considering their high nutritive value and have avoided SIS as trash fish. However, SIS contains a significant amount of protein, vitamins, calcium, iron, phosphorous, etc and they can be used to meet up the local nutritional demand. Moreover, SIS can also be used as a potential export item because of their high demand in USA, Japan and EU countries through which Bangladesh can earn a huge amount of foreign exchange. However, SIS are among the highly putrescent fishery commodities and easily loses its quality by microbial attack (5). So, it is necessary to assess the microbial load of the processed products during raw and frozen state because the presence of pathogenic bacteria such as Vibrio cholerae, Salmonella spp. etc. in processed products may cause serious health complexities to the consumers as well as failure of a full exportable consignment (2).

The aim of microbiological examinations of fish products is to evaluate the possible presence of pathogenic bacteria or organisms of public health significance and to give an impression of the hygienic quality of the fish including temperature abuse and hygiene during handling and processing. Besides, it had a view to observe whether the microbial load in raw and frozen product of Chapila and Tengra were within the acceptable limits $\left(1 \times 10^{5} \mathrm{cfu} / \mathrm{g}\right)$ 
for total viable bacteria, $<100 \mathrm{MPN} / \mathrm{g}$ for total coliform, $10 \mathrm{MPN} / \mathrm{g}$ for fecal coliform and zero tolerance for Salmonella and $V$. cholerae $(6,7)$ as recommended by International Commission of Microbiological Specifications for Foods (ICMSF) and European Union (EU). Therefore, the present study was designed to assess the microbiological quality of raw and frozen Chapila and Tengra fish samples for raising food safety concern to promote international trade.

\section{MATERIALS AND METHODS}

The study was conducted in a fish processing plant named "ARK SEA FOOD LTD." located at industrial area in Chittagong, Bangladesh. The presence of total aerobic bacteria, total coliform, fecal coliform, Salmonella spp. and V. cholerae in raw and frozen Chapila and Tengra samples were investigated in this study and a microbiological comparison between raw and frozen product was also demonstrated. During the study period, 3 samples of each of the fish products were examined.

Detection of total aerobic bacteria and total coliform. The aerobic plate count was determined by inoculating the samples on nutrient agar by streak plate method (6). For the detection of total coliform, most probable number (MPN) technique was applied. Twenty grams of the sample was blended for 1 min with $180 \mathrm{ml}$ of sterile dilute $0.1 \%$ peptone and serially diluted up to $10^{-5}$. Solution of $10^{-1}, 10^{-2}$ and $10^{-3}$ with Durham's tubes were incubated at 37 ${ }^{\circ} \mathrm{C}$ for 48 hours. After 48 hours, formation of gas in the Durham's tubes was considered sufficient evidence for the presence of coliform.

Detection of Salmonella spp. Twenty five grams sample was taken in $225 \mathrm{ml}$ sterile buffered peptone water ( $\mathrm{pH} 7.5$ ) aseptically and incubated for 48 hours at $37{ }^{\circ} \mathrm{C}$ for pre-enrichment. $1 \mathrm{ml}$ of pre-enrichment medium was then pipetted to selective enrichment medium namely selenite cystine broth and incubated for 24 hours at $37{ }^{\circ} \mathrm{C}$. One loopful of medium was streaked onto pre-dried selective plating medium, viz. brilliant green agar and xylose lysine deoxycholate agar and incubated for 24 hours at $37^{\circ} \mathrm{C}$

Pink, red, convex, entire glossy colonies surrounded by brilliant red zones in the brilliant green agar and black centered, convex, entire glossy colonies on xylose lysine deoxycholate agar would be suspected as Salmonella spp. Several biochemical tests such as lysine, dulcitol, malonate, indole, lactose, sucrose, MRVP, citrate utilization etc. were conducted for the further confirmation of Salmonella spp. according to the protocol of American Society of Microbiology with some modifications (8). All cultures giving biochemical reactions were confirmed by agglutination test with Salmonella polyvalent $(\mathrm{O})$ somatic antisera (9).

Detection of $\boldsymbol{V}$. cholerae. Twenty five gram of the composite sample was added in $225 \mathrm{ml}$ of sterile alkaline peptone water aseptically and incubated at $37^{\circ} \mathrm{C}$ for 24 hours. Loopful from alkaline peptone water was streaked on the surface of separate plates of thiosulfate citrate bile salt sucrose (TCBS) agar in such a manner to obtain individual colony and incubated at $37{ }^{\circ} \mathrm{C}$ for 24 hours. After 24 hours, $V$. cholerae colony was observed. The colony of $V$. cholerae was plain, yellow colored and large in size (generally 2-3 mm). From TCBS, the selected colony was transferred to triple sugar iron (TSI) agar slant by streaking. Then, TSI agar tubes are incubated at $37^{\circ} \mathrm{C}$ for 24 hours.

\section{RESULTS AND DISCUSSION}

Aerobic Plate Count (APC) in raw and frozen Chapila and Tengra. The density of total aerobic bacteria detected in all the raw samples of Chapila was comparatively higher than that of processed frozen Chapila (Fig. 1). The international accepted limit of APC recommended by ICMSF (1986) and EU (2005) for fresh and frozen fish is $1 \times 10^{5} \mathrm{cfu} / \mathrm{g}$ as mentioned previously $(6,7)$. The APC in raw and frozen product of Chapila and Tengra was found to be in the acceptable limit ranged between $0.8 \times 10^{5} \mathrm{cfu} / \mathrm{g}$ to $3.2 \times 10^{5} \mathrm{cfu} / \mathrm{g}$. Similar results was observed by Reza et al., (10) in 2009 for Silver Jewfish, Bombay duck, big-
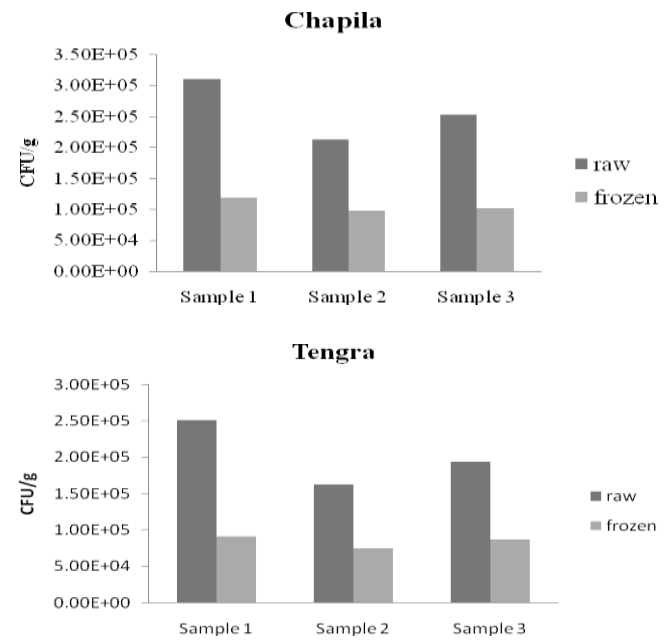

FIG. 1. Density (cfu/g) of total aerobic bacteria detected in 3 samples each of raw and frozen Chapila and Tengra. The bacterial load was found to be higher in the raw samples, especially in the sample 1 of both the fishes.

eye Tuna, Chinese Pomfret and Ribbon Fish. In their study, APC ranged between $1.1 \times 10^{5} \mathrm{cfu} / \mathrm{g}$ to $6.7 \times 10^{4} \mathrm{cfu} / \mathrm{g}$ (10). Moreover, similar findings has also been observed in Hilsha as $1.6 \times 10^{5} \mathrm{cfu} / \mathrm{g}$ by Salim in 2005 (11); in shrimp as $1.3 \times 10^{6}$ to $3.0 \times 10^{6} \mathrm{cfu} / \mathrm{g}$ by Janice and Lee in 1968 (12); in raw block frozen shrimp as $8.1 \pm 0.47 \times 10^{4}$ $\mathrm{cfu} / \mathrm{g}$ and in cooked IQF shrimp as $1.30 \pm 0.29 \times 10^{3} \mathrm{cfu} / \mathrm{g}$ by Hossain et al., (13) in 2010.

Total Coliform observed in raw and frozen Chapila and Tengra. Total coliform observed in raw samples of Chapila were $43 \mathrm{MPN} / \mathrm{g}, 29 \mathrm{MPN} / \mathrm{g}$ and $36 \mathrm{MPN} / \mathrm{g}$ in sample 1, 2 and 3, consecutively. The mean value was found to be $36.00 \pm 2.33 \mathrm{MPN} / \mathrm{g}$ (Table 1). In processed frozen Chapila, total coliform in sample 1, 2 and 3 were 9.2 MPN/g, 6.1 MPN/g and 6.2 MPN/g, consecutively. It was observed that in both raw and frozen state, sample 1 contain more coliform bacteria than samples 2 and 3 (Table 1). In raw Tengra, $38 \mathrm{MPN} / \mathrm{g}, 20 \mathrm{MPN} / \mathrm{g}$ and 23 MPN/g total coliform was observed in sample 1, 2 and 3, consecutively and the mean for raw Tengra was $27.00 \pm 5.57 \mathrm{MPN} / \mathrm{g}$. Whereas, in processed frozen Tengra, a mean value of $9.4 \pm 3.75 \mathrm{MPN} / \mathrm{g}$ for coliform was determined (Table 1). As previously mentioned, the acceptable limit of Total coliform recommended by ICMSF (1986) and EU (2005) for fresh and frozen fish is $<100 \mathrm{MPN} / \mathrm{g}(6,7)$. The Total coliform of all samples were also within the acceptable range. The findings of this study is similar to the findings of Hossain et al., (13) in processed black tiger shrimp ( $<3 \mathrm{MPN} / \mathrm{g}, 21 \mathrm{MPN} / \mathrm{g}$ and 5 $\mathrm{MPN} / \mathrm{g}$ total coliform in cooked IQF shrimp, raw block frozen shrimp and raw IQF shrimp, consecutively).

Fecal coliform in raw and frozen products of Chapila and Tengra. Fecal coliform is a facultative- 
TABLE 1. Total Coliform observed in 3 samples of raw and frozen Chapila and Tengra

\begin{tabular}{cccccc}
\hline $\begin{array}{c}\text { Product } \\
\text { Name }\end{array}$ & Condition & $\begin{array}{c}\text { Sample } \\
1\end{array}$ & $\begin{array}{c}\text { Sample } \\
2\end{array}$ & $\begin{array}{c}\text { Sample } \\
3\end{array}$ & $\begin{array}{c}\text { Mean } \\
\pm \text { SEM }\end{array}$ \\
\hline \multirow{5}{*}{ Chapila } & Raw & 43 & 29 & 36 & 36.00 \\
& $\begin{array}{c}\text { (MPN/g) } \\
\text { Frozen }\end{array}$ & 9.2 & 6.1 & 6.2 & $\begin{array}{c} \pm 2.33 \\
\text { (MPN/g) }\end{array}$ \\
& & & & 1.01 \\
& Raw & 38 & 20 & 23 & 27.00 \\
Tengra & (MPN/g) & & & & \pm 5.57 \\
& Frozen & 16 & 3.0 & 9.2 & $9.4 \pm$ \\
& $(\mathrm{MPN} / \mathrm{g})$ & & & & 3.75 \\
\hline
\end{tabular}

anaerobic, rod-shaped, Gram-negative, non sporulating bacterium capable of growing in the presence of bile salts or similar surface agents, is oxidase negative and produce acid and gas from lactose within 48 hours at $44 \pm 0.5^{\circ} \mathrm{C}$. Faecal coliform are considered to be present especially in the gut and feces of warm-blooded animals. The origin of faecal coliforms is more specific than the origin of the coliform group (14).

For raw Chapila, fecal coliform in sample 1,2 and 3 were found to be $6.2 \mathrm{MPN} / \mathrm{g}, 3 \mathrm{MPN} / \mathrm{g}$ and $3.6 \mathrm{MPN} / \mathrm{g}$, consecutively. In case of frozen Chapila, $<3 \mathrm{MPN} / \mathrm{g}$ fecal coliform were found in all samples (Table 2). Again, fecal coliform observed in sample 2 and 3 of raw Tengra was $3 \mathrm{MPN} / \mathrm{g}$, while in sample 1 it was 6.1 MPN/g. In case of frozen Tengra, the load of fecal coliform per gram of each sample was <3 MPN/g (Table 2).

TABLE 2. Fecal coliform observed in 3 samples of raw and frozen Chapila and Tengra

\begin{tabular}{|c|c|c|c|c|}
\hline $\begin{array}{c}\text { Product } \\
\text { Name }\end{array}$ & Condition & Sample 1 & Sample 2 & Sample 3 \\
\hline & $\begin{array}{c}\text { Raw } \\
\text { (MPN/g) }\end{array}$ & 6.2 & 3.0 & 3.6 \\
\hline Chapila & $\begin{array}{l}\text { Frozen } \\
(\mathrm{MPN} / \mathrm{g})\end{array}$ & $<3$ & $<3$ & $<3$ \\
\hline \multirow{2}{*}{ Tengra } & $\begin{array}{c}\text { Raw } \\
\text { (MPN/g) }\end{array}$ & 6.1 & 3.0 & 3.0 \\
\hline & $\begin{array}{l}\text { Frozen } \\
(\mathrm{MPN} / \mathrm{g})\end{array}$ & $<3$ & $<3$ & $<3$ \\
\hline
\end{tabular}

The international acceptable limit of fecal coliform recommended by ICMSF (1986) and EU (2005) for fresh and frozen fish is $10 \mathrm{MPN} / \mathrm{g}$. From the table 2, it was evident that fecal coliform in sample-1, sample-2 and sample-3 were <3MPN/g both in raw and frozen condition, which is lower than the recommended value. Therefore, the products of Chapila and Tengra were within acceptable quality for export.

Presence of Salmonella spp. and V. cholerae in raw and frozen Chapila and Tengra. Salmonella spp. and $V$. cholerae in aquaculture products mainly originates from the environment rather than from poor standards of hygiene and sanitation. But sometimes, incidence of these bacteria in fish, shrimp or similar foods of aquatic habitats may occur due to external contamination. Marine waters generally considered being free of Salmonella spp., estuaries and coastal waters contaminated with human and agricultural wastes pose a human health hazard. At the same time, the development of aquaculture has generated another important source of Salmonella spp.; contamination in fish and fish products. If Salmonella spp. and $V$. cholerae are found in fish samples then it would be rejected. However, in the present investigation, no $V$. cholerae and Salmonella spp. were found in any of the samples of Chapila or Tengra which indicate that the microbiological quality of Chapila or Tengra products were acceptable and good enough for export.

\section{CONCLUSION}

The present study reveals that microbiological quality of the investigated processed frozen products of Chapila and Tengra were within the acceptable limit, so it is assumed that these fish were harvested from a pollution free water body and preserved properly in chilled condition and were further processed in proper way. So these products maintained proper qualities for export purpose. Furthermore, total coliform, fecal coliform, total bacterial count found in raw fishes were significantly higher than those of processed frozen fishes. This indicates that processed frozen fishes were better than the raw fishes from the microbiological point of view.

\section{ACKNOWLEDGEMENT}

The authors are grateful to the authorities of "ARK SEA FOOD LTD.”, Chittagong, Bangladesh for providing their facilities to do research in the processing plant and also for their guidance.

\section{REFERENCES}

1. DoF (Department of Fisheries). 2006. Fishery statistical yearbook of Bangladesh 2004-2005. Fisheries resources survey system, department of fisheries (Dof), ministry of fisheries and livestock, Dhaka, Bangladesh.

2. Noor, R., et al. 2013. Microbiological study of major sea fish available in local markets of Dhaka city, Bangladesh. J. Microb. Biotech. Food Sci. 2 (4): 2420-2430.

3. Antony, M. M., G. Jeyasekaran, R. J. Shakila, and S. A. Shanmugam. 2002. Microbiological quality of raw shrimps processed in seafood processing plants of Tuticorin, Tamil Nadu, India. Asian Fisheries Sci. 15: 33-41.

4. DoF (Department of Fisheries). 2011. Fishery statistical yearbook of Bangladesh 2009-2010. Fisheries resources survey system department of fisheries (Dof), ministry of fisheries and livestock, Dhaka, Bangladesh.

5. Ahmed, M. K. 1999. Solving of systematic sea food quality problems cross functional team in the fish processing plants of Bangladesh. Paper read to the 4th Annual Quality Convention Proceedings, Dhaka, Bangladesh.

6. ICMSF (International Commission of Microbiological Specification for Food). 1982. Sampling for microbiological analysis: Principles and specific applications. Microorganisms in food. International Commission on the Microbiological Specification of Foods. Toronto Press, Toronto, Canada.

7. EU (European Union). 2005. Causes of detentions and rejections in international fish trade, 2nd ed. European Union, Blackwell Scientific Publications, p. 152-163.

8. American Society of Microbiology. 1981. Manual for general bacteriology. Available at: http://ourfood.com/General_bacteriology (Accessed 3 March, 2012). 
9. Surendran, P. K., N. Thampuran and K. Gopakumar. 1995. Microbial profile of cultured fishes and prawn viz a viz their spoilage and contamination. FAO Fish. Rep. No. 514 Suppl. FAO, Rome, Italy.

10. Reza, M. S., et al. 2009. Shelf life of several marine fish species of Bangladesh during ice storage. Int. J. Food Science and Technology 44 1485-1494.

11. Salim, G. M. 2005. A Study on the bacteriology of smoked thai Pangas (Pangasiushypophthylmu). M. Sc. Thesis, Bangladesh Agricultural University, Mymensingh, Bangladesh.
12. Janice, M. H. and J. S. Lee. 1968. Microbiological evaluation of pacific shrimp processing. Applied Microbiology, American Society for Microbiology 18: 2.

13. Hossain, A., et al. 2010. Microbiological quality of processed frozen black tiger shrimps in fish processing plant. World Journal of Fish and Marine Sciences 2: 124-128.

14. CDC (Center for Disease Control and Prevention). 2005. Escherichia coli Available at:

http://www.cdc.gov/ncidod/dbmd/diseaseinfoescherichiacolig.htm (Accessed 18 March, 2012). 